\title{
The Connection between the Increase in Foreign Reserves around the Globe and the U.S Collection of Seignorage Revenue
}

\author{
Winer Zvi \\ Department of Economics, Western Galilee Academic College, Israel \\ E-mail: ZvikaV@wgalil.ac.il
}

Ben David Evyatar

Analyst at Excelence investment Company, Israel

E-mail: evbd11@gmail.com

Ben David Nissim

Department of Economics and Management

The Max Stern Academic College of Emek Yezreel, Israel

E-mail: nissimb@yvc.ac.il

Received: December 29, 2017 Accepted: January 17, 2018

doi:10.5296/ber.v8i1.12789 URL: https://doi.org/10.5296/ber.v8i1.12789

\begin{abstract}
This paper sheds light on the large seignorage revenue collected by the U.S government resulting from the increase in dollar holding by foreign governments in their foreign reserves. In order to explore the connections between U.S seignorage revenue and other countries foreign reserves we estimated an equation linking between the foreign reserves of several foreign countries and the US monetary base. Our results show a strong connection between the foreign reserves of China, Japan and UK and the US monetary base.
\end{abstract}

Keywords: Seignorage, Foreign reserves

JEL: E4, E5, F4 


\section{Introduction}

A government's ability to collect seignorage revenue is a well-known fact. This ability is influenced by individuals' willingness to absorb the money being printed by the government. By mentioning the term individuals, the first thought that comes to one's mind is the local citizens. Nevertheless, one should consider the possibility that foreign countries also have the potential to absorb printed money, enabling an additional source of seignorage revenue.

The U.S. started earning considerable seignorage by printing dollars for other countries' reserves when the international monetary system was laid out by the Bretton Woods system in the mid- $20^{\text {th }}$ century. This system intended to determine the monetary relations among nations and has led to the situation in which the dollar is being used as the global reserve currency. This extraordinary status of the U.S. dollar also yields a special status to the U.S. However, only since 2009 we have noticed a huge increase in the amount of money printed, accompanied by a permanent current account deficit leading to the exporting of dollars to smaller economies which accumulate huge foreign exchange reserves. Beyond the implications of the enormous levels of U.S. deficit, this gives rise to the possibility for the U.S. to collect seignorage not just from local citizens, but from foreigners as well.

\section{Literature Review}

It was back in 1957 when Triffin (1957) recognized the problem of foreign countries' reserves movement that is a cause of the special class of the Dollar. "The enormous improvement of foreign countries' reserves which has taken place in recent years has been primarily the result of a vast redistribution of net reserves from the United States to the rest of the world. . . . It is evident that such a movement could not continue indefinitely without eventually undermining confidence in the dollar itself" (pp. 296-297).

In most cases researchers dealt with the connection between local inflation and seigniorage collection ignoring the possibility of seigniorage collection abroad. For instance, Neumann (1992) analyzed the relationship between monetary and fiscal seigniorage and inflation in the United States, from 1951 to 1990, and found that if the rate of inflation exceeds the rate of 7 percent the seigniorage falls short from the optimal level.

Fischer (1982) refer to the motivation of holding foreign money as a result of high local inflation: "As a country's inflation rate increases, there is typically a shift away from the domestic money toward a foreign money-as store of value, as unit of account, and as medium of transactions. This process is known as dollarization". Country with high rate of inflation drive a process of movement away from the local currency. This process, eventually, damages the ability of governments to collect seigniorage. This issue must be followed by the question of the benefit the U.S is gaining from such a movement by foreign countries, namely, the seigniorage it can collect.

Kumhof and Yan (2016) brought the case of China and Switzerland, which experienced huge foreign exchange reserve accumulation, crossing the optimal level. The researchers claim that this level of trade balance foreign reserve serves as an anti- crisis tool for those countries. They refer to these phenomena as "accepting the debasement of the US dollar". Dooley, 


\section{Macrothink}

Folkerts-Landauand and Garber (2003) argued that the role the U.S. played as the central country would continue because other economies had their own interest in keeping the strategy of export-led growth supported by accumulation of reserve asset claims on the central country. Judson (2011) stated that U.S. currency has long been a desirable medium of exchange in places where the local currency or bank deposits were inferior. Therefore, as Porter and Judson (1996) estimated, roughly $70 \%$ of U.S. currency is held abroad. A substantial share of U.S. currency circulates outside the United States. However, the superiority of the US is not immune and Liao and McDowell (2015) found evidence that 37 central banks have added China's Renminbi (RMB) to their reserve portfolio since 2010. Krugman (2007) also pointed out to the resemblance between the current US situation and that of developing countries in the sense that if capital inflows abruptly will cease, the currency plunged, and the economy will experienced a major setback

\section{The U.S ability to Collect Seignorage}

The U.S. has a huge external debt, amounting to 17.6 trillion dollars. The annual U.S. current account deficit is 2.7 percent of the GDP, 124.1 billion dollars. This size of external debt should have caused the dollar to decline relative to other currencies.

The interest rate in the U.S. is slightly higher than in other countries, but this gap is too small to serve as the reason, or explanation, for the stability of the exchange rate for the dollar.

More in-depth thinking gives rise to a more complex picture than just an external determining of the exchange rate. The demand for the U.S. currency stems not just from export and import, but also from some kind of confidence nations are striving to achieve. This confidence is parallel to the demand of individuals for money. Holding money is not costless, however individuals demand for money stems from the fact that money gives them sort of freedom to capitalize opportunities conditioned on available and readily money. Nations holding U.S. currency creates a huge demand for dollars in order to extend their foreign currency of the worlds' largest economy. Increasing their foreign reserve of U.S. dollars, raises any country's relative ranking. It portrays a picture of a stable economy, eases local investment, and attracts foreign investors. The U.S., therefore, earns the seignorage revenues from being the greatest economy in the world.

As the graphs below shows, stylized facts reveal that the U.S. currency supply has increased by more than $600 \%$ since 2000 . At the same time, the foreign currency reserves, in dollars, in other counties increased significantly as well. 


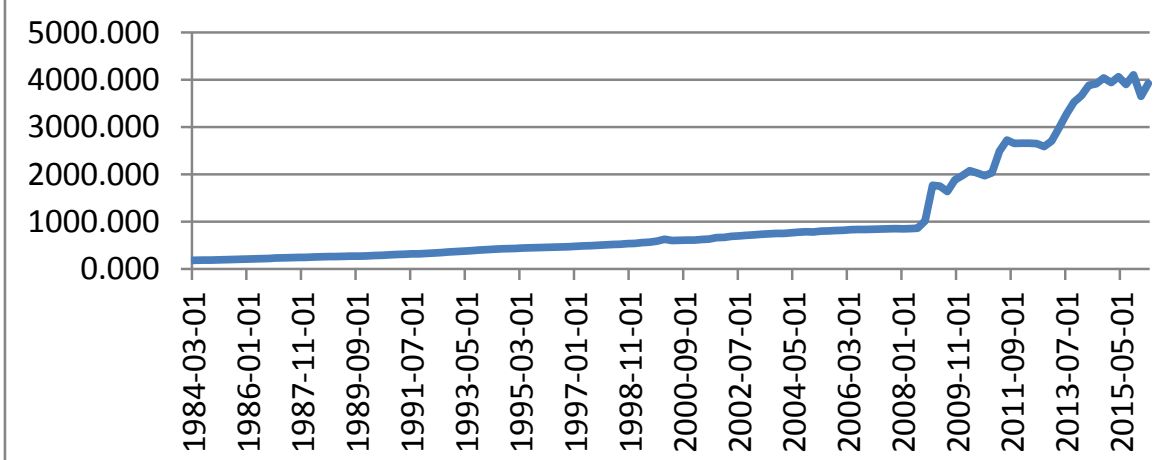

Figure 1. Monetary Base in U.S. in Billions of Dollars

Source: Federal Reserve Bank of St. Louis, https://fred.stlouisfed.org/series/BASE

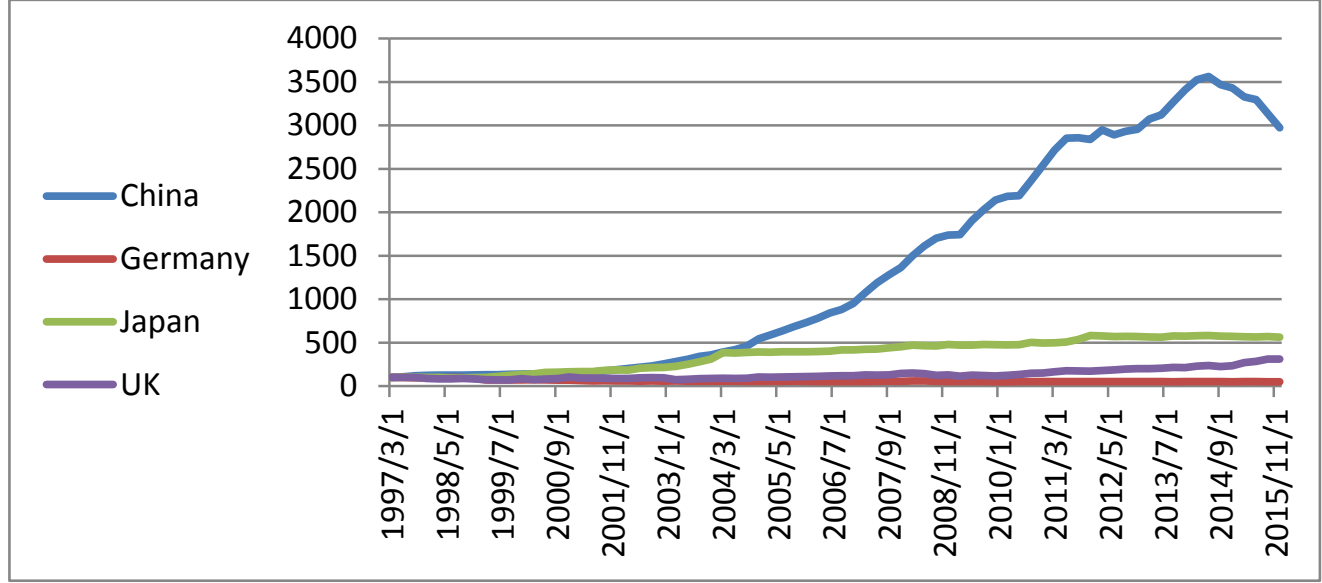

Figure 2. International Reserves Index, Specific Countries

Source: Bloomberg data base

In Figure 1 we can see a steady growth in printed Dollars which comes to its peak at September 2015 while in Figure 2 we can see a steady increase in foreign international reserves in U.K, Japan, Germany and mainly in China which point to the fact that Printed Dollars is held in increasing amounts by foreign countries.

Table 1 presents the change in U.S. monetary base and yearly current account.

Table 1 . The change in U.S monetary base and yearly current account

\begin{tabular}{|c|c|c|}
\hline Date & $\begin{array}{c}\text { Balance in Current Account } \\
\text { in billions of Dollars }\end{array}$ & $\begin{array}{c}\text { Change of Monetary Base in } \\
\text { billions of Dollars }\end{array}$ \\
\hline 1986-01-01 & -142.7 & 12.351 \\
\hline $1987-01-01$ & -154.1 & 18.184 \\
\hline $1988-01-01$ & -115.8 & 21.317 \\
\hline $1989-01-01$ & -92.4 & 18.267 \\
\hline
\end{tabular}

\footnotetext{
${ }^{1}$ Change in the monetary base was calculated from the original series of monetary base data published for dates that were close to end of a quarter.
} 


\begin{tabular}{|c|c|c|}
\hline $1990-01-01$ & -74.9 & 14.388 \\
\hline $1991-01-01$ & 7.9 & 14.651 \\
\hline $1992-01-01$ & -45.6 & 29.865 \\
\hline $1993-01-01$ & -78.5 & 24.890 \\
\hline $1994-01-01$ & -114.7 & 37.485 \\
\hline $1995-01-01$ & -105.1 & 42.543 \\
\hline $1996-01-01$ & -114.1 & 25.586 \\
\hline $1997-01-01$ & -129.3 & 16.110 \\
\hline $1998-01-01$ & -204.5 & 27.838 \\
\hline $1999-01-01$ & -286.6 & 30.440 \\
\hline $2000-01-01$ & -403.7 & 39.974 \\
\hline $2001-01-01$ & -388.8 & 43.915 \\
\hline $2002-01-01$ & -450.8 & 23.868 \\
\hline $2003-01-01$ & -515.7 & 63.563 \\
\hline $2004-01-01$ & -627.0 & 46.944 \\
\hline $2005-01-01$ & -737.7 & 27.117 \\
\hline $2006-01-01$ & -802.2 & 34.974 \\
\hline $2007-01-01$ & -718.1 & 32.356 \\
\hline $2008-01-01$ & -691.6 & 14.584 \\
\hline $2009-01-01$ & -381.9 & 323.639 \\
\hline $2010-01-01$ & -445.9 & 414.178 \\
\hline $2011-01-01$ & -481.5 & 168.237 \\
\hline $2012-01-01$ & -468.2 & 327.245 \\
\hline $2013-01-01$ & -386.1 & 89.201 \\
\hline $2014-01-01$ & -401.7 & 1789 \\
\hline $2015-01-01$ & & \\
\hline $2016-01-01$ & -47.4 & \\
\hline
\end{tabular}

Source: Federal Reserve Bank of St. Louis, https://fred.stlouisfed.org/series/BPBLTT01USQ637S

Table 1 shows that since 2009, the U.S. central bank has extremely increased the monetary base and that the U.S. current account is in a large deficit. At the same time, Figure 2 shows that China, Japan, and the U.K. have increased their reserves in large quantities, especially after 2009.

One of the biggest absorption of U.S currency has been made by China, allowing the U.S. to earn enormous seignorage revenue. This absorption of the U.S. currency reflects the country's confidence in the "great nation's economy", namely, the belief that it would be possible, at any time, to convert U.S. currency to substantial good or services.

If one adopts the assumption that foreign countries want to keep fixed foreign currency reserves, then escalation in the inflation in the U.S. would only allow the U.S to earn additional seignorage revenue. 


\section{Ml Macrothink}

Business and Economic Research ISSN 2162-4860 2018, Vol. 8, No. 1

According to the data presented above, we can see that the U.S. continues printing large amounts of money without suffering from inflation. The U.S. will continue to collect seignorage from other countries as long as foreign countries are confident that the U.S. is the strongest and largest economy. However, if Chinas' or other large countries' economies will grow to the size of the U.S., the U.S will have to share this seignorage income with other countries and will be forced to improve its current account deficit.

\section{Estimating the Effect of Foreign Countries' Reserves on American Monetary Base}

In this part we used OLS in order to estimated the connection between foreign countries' reserves, as well as American current account and American GDP, on the American monetary base.

We used quarterly time series data for the period 1997.1-20015.4 of foreign reserves in China, Japan, Germany and UK as well as American GDP and American Current account as explanatory variables of the Money Base in U.S. Since series were not stationary we used the rate of change in each series and examined the stationarity of the series.

Table 1 presents the results of stationarity tests of the various series by applying the Augmented Dickey-Fuller Test.

Table 2. Augmented Dickey-Fuller Test

\begin{tabular}{|l|l|l|l|l|}
\hline $\begin{array}{l}\text { Null Hypothesis: variable } \\
\text { has a unit root }\end{array}$ & $\begin{array}{l}\text { Augmented } \\
\text { Dickey-Fuller } \\
\text { statistic }\end{array}$ & Prob. & $\begin{array}{l}\text { Test critical } \\
\text { values: 1\% level }\end{array}$ & $\begin{array}{l}\text { Test } \\
\text { values: 5\% level }\end{array}$ \\
\hline $\begin{array}{l}\text { China - (rate of change in China } \\
\text { Reserves) }\end{array}$ & -3.185356 & 0.0248 & -3.521579 & -2.901217 \\
\hline $\begin{array}{l}\text { Germany - (rate of change in } \\
\text { Germany Reserves) }\end{array}$ & -7.115552 & 0.0000 & -3.521579 & -2.901217 \\
\hline $\begin{array}{l}\text { Japan - (rate of change in Japan } \\
\text { Reserves) }\end{array}$ & -5.670108 & 0.0000 & -3.521579 & -2.901217 \\
\hline $\begin{array}{l}\text { UK - (rate of change in UK } \\
\text { Reserves) }\end{array}$ & -8.673365 & 0.0000 & -3.521579 & -2.901217 \\
\hline $\begin{array}{l}\text { MoneyB (rate of change in } \\
\text { American Money Base) }\end{array}$ & -7.795338 & 0.0598 & -3.521579 & -2.901217 \\
\hline $\begin{array}{l}\text { Current (rate of change in } \\
\text { American Current Account) }\end{array}$ & -2.825642 & 0.0001 & -3.521579 & -2.901217 \\
\hline $\begin{array}{l}\text { GDP (rate of change in } \\
\text { American GDP) }\end{array}$ & -5.015985 & & \\
\hline
\end{tabular}

*MacKinnon (1996) one-sided p-values

As we can see all rate of change series are stationary at significant level of below $6 \%$ (most series are significantly stationary at a significant rate of $0 \%$ while rate of change in China Reserves is significantly stationary at $2.48 \%$ and rate of change in American Current Account is significantly stationary at a significant rate of $5.95 \%$ ). 
Since the American monetary policy has been changed drastically following the 2008 depression, we added a dummy variable defined as 0 before quarter 1 in 2008 and 1 at the following quarters (The dummy variable is defined as DD).

The estimated equation is:

$$
\begin{aligned}
& \text { MoneyB }_{t}=\alpha+\beta_{1} \text { China }_{t}+\beta_{2} \text { China }_{t} * D D+\beta_{3} \text { Germany }_{t}+\beta_{4} \text { Germany }_{t} * D D+ \\
& +\beta_{5} \text { Japan }_{t}+\beta_{6} \text { Japan }_{t} * D D+\beta_{7} \text { UK }_{t}+\beta_{8} U K_{t} * D D+\beta_{9} \text { Current }_{t}+\beta_{10} \text { Current }_{t} * D D \\
& +\beta_{11} \text { GDP }_{t}+\beta_{12} \text { GDP }_{t} * D D+U_{t}
\end{aligned}
$$

Equation (1) estimate the connection between the rate of change in American Money Base as a dependent variable while explanatory variables are the rate of change in Reserves in China, Germany, Japan and U.K as well as a dummy variable having a value of 0 before 2008 and a value of 1 following 2008. An interaction between the dummy variable and the rate of change in Reserves in China, Germany, Japan and U.K is added as well as explanatory variables to the regression.

The coefficient of the variables: China, Germany, Japan and UK reflects the elasticity between U.S monetary base (Printed money in U.S) and the reserves before 2008. The coefficient of the variables: China*DD, Germany*DD, Japan*DD and UK*DD reflects the change in elasticity between U.S monetary base (Printed money in U.S) and the reserves after 2008 comparing to the period before 2008 . The $\beta_{9}$ and $\beta_{10}$ coefficients reflect the impact of the US current account on its' monetary base, before and after 2008 while the $\beta_{11}$ and $\beta_{12}$ coefficients reflect the impact of the US GDP on its' monetary base, before and after 2008.

Regression results after removing nonsignificant variables is presented in Table 3:

Table 3. Regression Results

\begin{tabular}{|l|l|l|l|l|}
\hline Variable & Coefficient & Std. Error & t-Statistic & Prob. \\
\hline C & 0.066252 & 0.018596 & 3.562725 & 0.0007 \\
\hline CHINA*DD & 0.715222 & 0.408444 & 1.751089 & 0.0844 \\
\hline CURRENT*DD & -0.131892 & 0.075935 & -1.736917 & 0.0869 \\
\hline UK*DD & 0.608633 & 0.298822 & 2.036775 & 0.0456 \\
\hline GDP*DD & -4.168085 & 2.214777 & -1.881943 & 0.0641 \\
\hline JAPAN*DD & 1.414912 & 0.676968 & 2.090073 & 0.0404 \\
\hline GDP & -3.743152 & 1.569195 & -2.385396 & 0.0199 \\
\hline R-squared=0.2944 \\
\hline
\end{tabular}

We can see that before 2008 there is no connection between American monetary base and the foreign reserves in Germany, China, Japan and U.K. However, after 2008 the foreign reserves in China, UK and Japan have a strong connection with the American monetary base. The foreign reserves in Germany does not affect the American monetary base at any time.

The negative effect of the GDP in US on its monetary base is calling for an additional attention. One of the possible explanations for the negative connection is that GDP is the tax 
base for collecting taxes, such that an increase in GDP, in the United States will be accompanied by an increase in the total tax revenue. Therefore, there is less pressure to increase the monetary base to finance the governments' budget.

\section{Concluding Remark}

The U.S. ability to collect seignorage is undoubtedly influenced by its size. The U.S. government capitalizes on foreign countries' willingness to hold U.S. dollars.

According to our findings, since 2008 China, UK and Japan foreign reserves are strongly connected with the American monetary base. Since series are in terms of rate of change the coefficients represent the elasticity between each explanatory variable and the monetary base. We found that an increase in Japans foreign reserves by 1 percent would increase American monetary base by 1.4 percent while the same increase in china or UK reserves would increase American monetary base by $0.71 \%$ and $0.608 \%$, respectively.

However, according to relevant literature (see for example, Liao and McDowell (2015)) no one can guarantee the continuation of the phenomenon in the future. The signs that a new currency will displace the U.S. currency as the anchor already exist.

We highlight the following insights from the data and the empirical estimation we presented:The U.S. is earning considerable seignorage by printing dollars for other countries' reserves.

Foreign countries are holding U.S currency for various reasons such as anti- crisis tool, dollarization, and as desirable medium of exchange.

There is no guaranty that the U.S currency will continue having the same role in the future and the signs that a f new currency will displace the U.S. currency already exist.

\section{Policy Recommendations}

There is no doubt that the U. S is earning a huge amount of seigniorage collection. However, the U.S Federal authorities must not ignore early signs of U.S Dollar losing its' status among foreign countries. Therefore, the U.S government should take early steps in order to prevent crises. Such steps might include balancing the U.S government budget and decreasing the amount of printed U.S Dollars in the coming years.

\section{References}

Dooley, M. P., Folkerts-Landau, D., \& Garber, P. (2003). An essay on the revived Bretton Woods system (No. w9971). National Bureau of Economic Research. https://doi.org/10.3386/w9971

Fischer, S. (1982). Seigniorage and the Case for a National Money. Journal of political economy, 90(2), 295-313. https://doi.org/10.1086/261057

Judson, R. (2012). Crisis and Calm: Demand for US Currency at Home and Abroad from the Fall of the Berlin Wall to 2011. International Finance Discussion Paper 2012-1058, Board of Governors of the Federal Reserve System. Washington, DC (November). 
https://doi.org/10.2139/ssrn.2181978

Krugman, P. (2007). Will there be a dollar crisis?. Economic Policy, 22(51), 436-467. https://doi.org/10.1111/j.1468-0327.2007.00183.x

Kumhof, M., \& Yan, I. (2016). Balance-of-payments anti-crises. Journal of Macroeconomics, 48, 186-202. https://doi.org/10.1016/j.jmacro.2016.02.005

Liao, S., \& McDowell, D. (2015). Redback rising: China's bilateral swap agreements and renminbi internationalization. International Studies Quarterly, 59(3), 401-422.

https://doi.org/10.1111/isqu.12161

Neumann, M. J. (1992). Seigniorage in the United States: how much does the US government make from money production?. Federal Reserve Bank of St. Louis Review, 74(March/April 1992)

Porter, R. D., \& Judson, R. A. (1996). The location of US currency: How much is abroad. Fed. Res. Bull., 82, 883.

Triffin, R. (1957). Europe and Money Muddle. Yale University Press.

Triffin, R. (1978). Gold and the Dollar Crisis: Yesterday and Tomorrow. International Finance Section, Department of Economics, Princeton University.

\section{Copyright Disclaimer}

Copyright for this article is retained by the author(s), with first publication rights granted to the journal.

This is an open-access article distributed under the terms and conditions of the Creative Commons Attribution license (http://creativecommons.org/licenses/by/3.0/). 